\title{
Design of a seawater-source heat pump for a bridge heating system in winter season
}

\author{
Kıș sezonu köprü ısıtma sistemi için deniz suyu kaynaklı ısı pompası \\ dizaynı
}

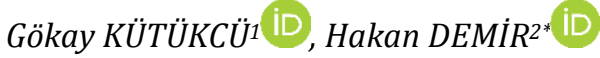 \\ 1,2Mechanical Engineering Department, Mechanical Engineering Faculty, Yıldız Technical University, Istanbul, Turkey. \\ kutukcug@gmail.com, hdemir@yildiz.edu.tr
}

Received/Geliș Tarihi: 28.03.2016, Accepted/Kabul Tarihi: 09.05.2017

doi: $10.5505 /$ pajes.2017.06926

* Corresponding author/Yazıșllan Yazar Research Article/Araștırma Makalesi

\begin{abstract}
In this paper, a seawater source heat pump system is designed for a bridge heating in winters. It is probable to freeze of the ways and bridges which may cause many accidents in the cold and snowy weathers. Snow melting system is necessary to prevent the possible accidents and privative situations. Design of the optimum pipe length of seawater heat exchanger is a critical issue to transfer the maximum heat from the sea. Effects of the pipe diameter, wall thickness, radius of the coil and coil pitch on the heat transfer were shown in this paper. Moreover, friction factor of the helicoidal pipes and energy consumption of pumps were also calculated.
\end{abstract}

Keywords: Slinky heat exchanger, Seawater-source heat pump Optimization, Freezing

\section{Introduction}

Seawater source heat pumps are used for commercial applications as water heating, cooling or heating of buildings. Especially, it is preferred in commercial buildings due to its high efficiency advantage and environmental friendliness in comparison to conventional systems. In the $20^{\text {th }}$ century, use of petroleum resources dominated all the process and electricity industry. Nowadays, humankind realized that world's petroleum resources are not infinite. Rapaciously consumption of petroleum resources caused their costs to rise. From 1945 to 2008, oil prices rose from $\$ 12$ /barrel to about $\$ 100 /$ barrel [1]. Hence, we need to give importance to alternative energy usage much more than before.

Heat pump, invention of a form of closed-loop cycle, is generally attributed to Lord Kelvin. The principal differences between the refrigerator, air-conditioning system and heat pump system are because of the way they are used. Refrigerator and air-conditioning system provide useful cooling, whereas heat pumps provide useful heating [2].

Heat pumps system can be in different types and different designs. For example Horizontal coupled ground source heat pump system could be used in three different types. These are single pipes, multiple-pipes and spiral-type system [3].

Sudiro and Bertucco [1] mentioned about optimization of the heat exchanger of a seawater source heat pump system applied in China. The most important optimization data is the icing and non-icing condition around the pipe [1]. Besides, by creating two mathematical model about the icing and nonicing condition, the effect of the seawater temperature and flow velocity in the pipe was shown [1].
Öz

Bu makalede, kıș aylarında köprü Isıtmada kullanılan deniz suyu kaynaklı bir pompası dizayn edilmistir. Kıșın özellikle karlı havalarda köprü ve yolların donması pek çok kazaya neden olmaktadır. Bu nedenle muhtemel kazaların önlenmesi açsından kar eritme sistemlerinin kullanılması gereklidir. Optimum boru boyunun belirlenmesi denizden Isı transferinin maksimum olması için önemli bir kriterdir. Bu çalıșmada boru çapı, et kalınlığı, sarmal çapı ve sarmal adımının ısı transferine etkileri incelenmiștir. Ayrıca, sarmal borulardaki sürtünme katsayısı ve pompaların enerji tüketimleri de hesaplanmiştır.

Anahtar kelimeler: Sarmal ısı değiștirici, Deniz suyu kaynaklı ısı pompası, Optimizasyon, Donma

Yu et al. [4] investigated a district heating system using a water source heat pump. Mostly, cost analysis of the energy consumption of the pumps and heat pumps has been done for hot water supply. Besides, the system was compared with the boiler system. It was aimed to determine if the system is economically useful or not.

Heat pumps system is being to more important for heating of various places. Haiwen et al. [5] designed a space heating system using heat pump and investigated if system is financially feasible or not by developing a mathematical model.

The differences between conventional horizontal system and slinky-coil horizontal loops could be seen Demir [6]. By composing a numerical simulation model, heat transfer analysis was conducted and the variation of the inlet and outlet temperature of fluid according to time was given. Besides, the calculated and measured values were compared each other.

Fujii et al. [7], a ground source heat pump application was presented and a numerical model about the slinky heat exchanger was given. The soil temperature distributions on a specific time were given. The heat dissipation around the heat exchanger was also given. They calculate the specific heat extraction rates for different band radiuses.

The spiral heat exchanger is usually used in Ground Source Heat Pump (GSHP) system and the GSHP system is generally used for indoor heating. Studies on ground heat exchangers have examined on field measurements and numerical analysis. Li et al. [8] focused not only the numerical analysis but also theoretical researches. The methodology is aimed to analyze 
the thermal performance of a spiral heat exchanger by establishing a ring source model.

\section{Heat transfer equations for the flow in circular straight ducts}

In this study, helicoidal pipes have been used instead of straight pipes. Moreover, in order to compare these two types of pipes, the heat transfer equation for the straight pipes has been shown additionally.

Nusselt number in the flow in circular ducts is defined with Colburn Equation [9]

$$
N u=0,023 \operatorname{Re}^{0,8} \operatorname{Pr}^{n}
$$

Here $n=0.4$ for heating and $n=0.3$ for cooling respectively.

Seider and Tate propose the equation given below for the fluid which has big characteristic changes [9].

$$
N u=0,027 \operatorname{Re}^{0.8} \operatorname{Pr}^{0.33}\left(\frac{\mu}{\mu_{s}}\right)^{0.14}
$$

The equation given above has some inaccuracy that may reach up to $25 \%$. It's possible to get more complicated equations to decrease the inaccuracy. The error rate can be reduced to $10 \%$ by the equation given below. The equation that belongs to Petukhov is [9]

$$
N u=\frac{(f / 8) \operatorname{Re} \times \operatorname{Pr}}{1.07+12.7\left(f_{/ 8}\right)^{0.5}\left(\operatorname{Pr}^{2 / 3}-1\right)}
$$

The following equation that is offered by Gnielinksi for low Reynolds numbers [9];

$$
N u=\frac{(f / 8)(R e-1000) \operatorname{Pr}}{1+12.7(f / 8)^{0.5}\left(\operatorname{Pr}^{2 / 3}-1\right)}
$$

\section{Heat transfer equations for the flow in circular slinky heat exchanger}

The most important characteristic of the flow in slinky heat exchanger is the curvature of the pipes (Figure 1). The friction factor is higher than friction factor in the straight pipes for the same Reynolds number. The pitch of the slinky heat exchanger has an effect on the heat transfer. Consequently, the heat transfer rate is higher in slinky heat exchanger than straight pipes. Thus, slinky heat exchangers are widely used in many applications.

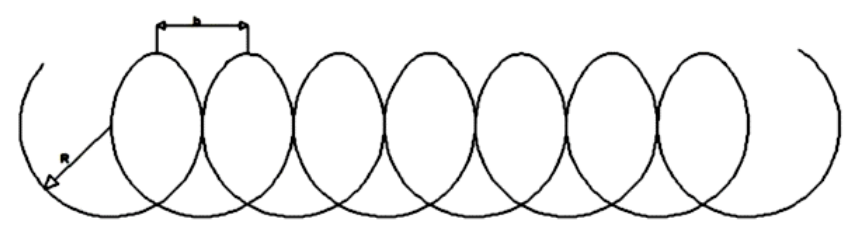

Figure 1: Slinky heat exchanger.

Dean Number is a kind of dimensionless number used in both spiral coils and helicoidal pipes.

$$
D e=R e \times\left(\frac{d_{i}}{R}\right)^{0.5}
$$

The pitch effect in the slinky heat exchanger is not too much important for an optimum design. The researches have shown that effect of the pitch is minimum on the heat transfer rate. When the experimental and theoretical results are compared, the regression analysis of available data is given by Reay and Macmichael [10]:

$$
N u=\left(\left(3.657+\frac{4.343}{x_{1}}\right)^{3}+1.158\left(\frac{D e}{x_{2}}\right)^{1.5}\right)^{0.33}
$$

Where $\mathrm{x}_{1}=\left(1+\frac{957}{\mathrm{De}^{2} \mathrm{Pr}}\right)^{2}$ and $\mathrm{x}_{2}=1+\frac{0.477}{\mathrm{Pr}}$

Heat transfer mechanism in the sea can be modeled as free convection if there is no current. Rayleigh number describes the relative magnitude of the buoyancy and viscous forces in the fluid:

$$
R a=\frac{g \beta(\Delta T) L_{c}^{3}}{v \alpha}
$$

For horizontal slinky heat exchanger, characteristic length is defined as the outer diameter of the pipe. Convection heat transfer coefficient of slinky pipes is defined as a function of Nusselt number in flow over horizontal pipes, since no specific correlation exist for slinky pipes. Nusselt number for free convection defined as [11]:

$$
\begin{gathered}
\left.\left.N u=\left(0.6+\frac{0.387\left(R a^{1 / 6}\right)}{(1+(0.559 / P r}\right)^{9 / 16}\right)^{\frac{8}{27}}\right)^{2} \\
N u=\frac{h_{\text {out }} k}{L_{c}}
\end{gathered}
$$

Total heat transfer rate for the bridge heating is $\dot{Q}(\mathrm{~kW}) . \mathrm{n}_{\mathrm{k}}$ number of sea water source heat pumps were used. Heat transfer rate for each heat pump and is $\dot{Q} / n_{k}(\mathrm{~kW})$. Hence the pipe length that provides the required heat in every section can be calculated as,

$$
\dot{Q}=\frac{\Delta T_{l m}}{\frac{1}{\pi D_{i} l h_{i}}+\frac{\ln \left(D_{o} / D_{i}\right)}{2 \pi k l}+\frac{r}{\pi D_{i} l}+\frac{1}{\pi D_{o} l h_{\text {out }}}}
$$

the pipe lengths can be calculated in every section and the total pipe length,

$$
\begin{gathered}
L=n_{m} l \\
\Delta T_{m}=\frac{\left(T_{\text {sea }}-T_{i}\right)-\left(T_{\text {sea }}-T_{o}\right)}{\ln \left[\frac{T_{\text {sea }}-T_{i}}{T_{\text {sea }}-T_{o}}\right]}
\end{gathered}
$$

Friction factor for straight pipes in turbulent flow is

$$
\begin{gathered}
f_{s}=0.317\left(R e^{-0.25}\right) \\
R e=\frac{v_{c} D_{i}}{\gamma} \\
Q_{f}=v_{c}\left(\frac{\pi D_{i}^{2}}{4}\right)
\end{gathered}
$$

For using slinky heat exchangers, curvature effects should be considered. Friction factor for slinky heat exchanger is higher than the friction factor for straight pipes. Following correlation was proposed by Chiasson [12] to calculate the friction factor for turbulent flow in slinky heat exchanger. 


$$
f_{c}\left(\frac{R}{a}\right)^{0.5}=0.00725+0.076\left(\operatorname{Re}\left(\frac{R}{a}\right)^{-2}\right)^{-0.25}
$$

where $0.034<\operatorname{Re}\left(\frac{R}{a}\right)^{-2}<300$.

Owing to high flow rate and friction factor, pressure drop in the pipe is very high and precautions must be taken for the high pressure drop. It means the circulation pumps consume much electricity. To save the electric energy it will be useful to use multiple heat exchangers in parallel instead of a single pipe. So the flow rate and friction factor are decreased.

For laminar flow, the friction factor for slinky heat exchanger [10];

$$
\begin{gathered}
\frac{f_{c}}{f_{s}}=0.125 D e^{0.5} \quad \text { De }>300 \\
f_{s}=64 / R e \quad R e<2300
\end{gathered}
$$

\section{The reference function}

By composing the reference function, it is aimed to get maximum heat transfer rate with minimum total cost. As the total cost, investment cost and operating cost has been regarded. The function to be optimized can be defined as below.

$$
F_{r}=\frac{\dot{Q}}{C_{i}+C_{e}}
$$

As annual investment cost, heat pumps, circulation pumps, pipe and fitting tools, valves etc. are taken into account. Consequently, $C_{i}$ is

$$
C_{i}=C_{i, \text { pump }}+C_{i, \text { heat pump }}+C_{i, \text { pipe }}
$$

Depreciation of investment cost for the slinky heat exchanger circulation pump and heat pump are given as follows:

$$
\begin{gathered}
C_{i \text { pump }}=b_{1} W \\
b_{1}=M_{\text {pump }} P \\
C_{i \text { heat } \text { pump }}=b_{2} W_{\text {heat pump }} \\
b_{2}=M_{\text {heat pump }} P \\
P=\frac{i(1+i)^{v}}{(1+i)^{v}-1}
\end{gathered}
$$

As the heat exchanger cost, only pipe cost has been regarded. The collectors, fittings and cost of labor were added with a certain percentage. Annual depreciation of pipe investment cost,

$$
\begin{aligned}
& C_{i \text { pipe }}=a_{\text {pipe }} L \\
& a_{\text {pipe }}=M_{\text {pipe }} P
\end{aligned}
$$

Annual operating cost is the expenses of electricity consumed by circulation pumps and heat pumps during the operating time.

$$
C_{e}=\left(b_{3} W_{\text {pump }}\right)+\left(b_{4} W_{\text {heat pump }}\right)
$$

A relationship between heating capacity of the heat pump $\left(W_{\text {heat pump }}\right)$ and its price is given as;

$$
M_{\text {heat pump }}=356.25 W_{\text {heat }} \text { pump }+9675.84
$$

A relationship between inner diameter of the pipe $\left(D_{i}\right)$ and its price $\left(M_{\text {pipe }}\right)$ is given as a linear equation.

$$
M_{\text {pipe }}=292.8 D_{i}-6.362
$$

A linear equation is also given between energy consumption of pumps $\left(W_{p}\right)$ and price of the pumps $\left(M_{\text {pump }}\right)$.

$$
M_{\text {pump }}=1706.56 \mathrm{~W}_{\text {pump }}+13.16
$$

\section{Keys of study}

The heat pump system has been designed to use in Black Sea Region of Turkey which is the near the Black Sea. Black Sea was used as the heat source and the average temperature in winter is about $10^{\circ} \mathrm{C}$. Fluid inlet temperature is $2{ }^{\circ} \mathrm{C}$ for design calculations. To avoid freezing of the water under the operating condition and in the winter, it must be taken some precaution. Therefore, water-ethylene glycol mixture is used in the system. Besides, the properties of the fluid and sea water are shown in Table 1 and Table 2. Heat capacity of the system is about $1300 \mathrm{~kW}$ and 13 heat pumps were used because of the high value of heat capacity of the system.

Table 1: Properties of water-ethylene glycol mixture.

\begin{tabular}{ccc}
\hline $25 \%$ by weight & Value & Unit \\
\hline Density & 1035 & $\mathrm{~kg} / \mathrm{m}^{3}$ \\
Specific Heat & 3.8 & $\mathrm{kj} / \mathrm{kg} \mathrm{K}$ \\
Kinematic & $3.2 \times 10^{-5}$ & $\mathrm{~m}^{2} / \mathrm{s}$ \\
Viscosity & 27.4 & - \\
Prandlt Number & & - \\
\hline
\end{tabular}

\begin{tabular}{ccc}
\hline \multicolumn{3}{c}{ Table 2: Properties of sea water } \\
\hline $0{ }^{\circ} \mathrm{C}$ & Value & Unit \\
\hline Kinematic Viscosity & $1.5 \times 10^{-6}$ & $\mathrm{~m}^{2} / \mathrm{s}$ \\
$\beta$ & $8.4 \times 10^{-5}$ & $1 / \mathrm{K}$ \\
Prandtl Number & 11.6 & - \\
\hline
\end{tabular}

\section{Results and discussions}

Effects of the different design parameters on the reference function were investigated. As seen from Figure 2, does not have significant effect on pipe length for less than $1 \mathrm{~m}$ of bend radius.

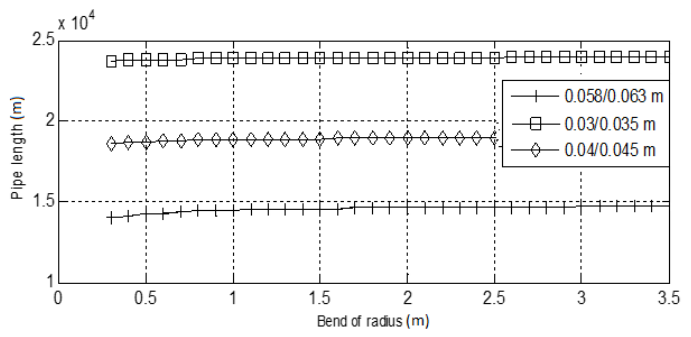

Figure 2: Relation between bend radius, pipe diameter and pipe length.

Effect of bend radius on energy consumption of circulation pump is given in Figure 3. Bend radius has an important effect on energy consumption for small pipe diameters. The reference function increases with increasing pipe inner diameter and passes through a maximum and then slightly decreases (Figure 4). In Figure 5, effect of bend radius on the 
reference function is given. Increasing bend radius increases the reference function. Also, seawater temperature has important effect on the reference function (Figure 6).

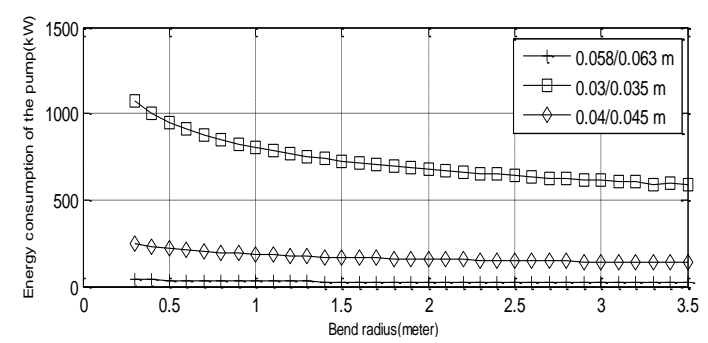

Figure 3: Relation between bend radius and energy consumption of the pump for different pipe diameters.

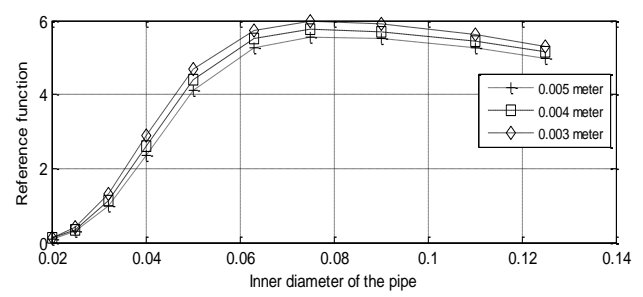

Figure 4: Effect of the wall thickness of the pipe on the reference function.

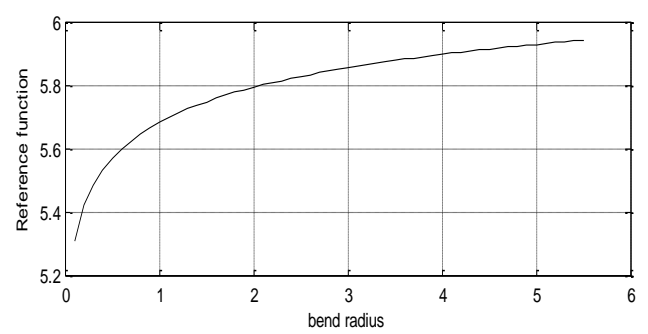

Figure 5: Effect of the bend radius on the reference function.

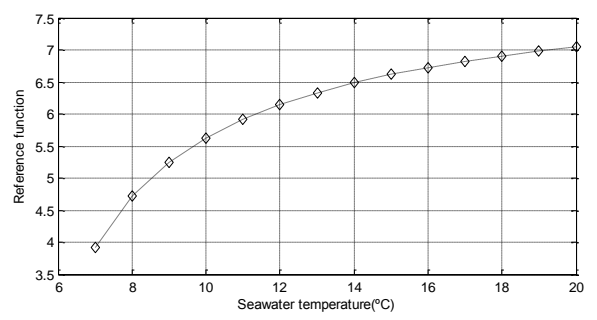

Figure 6: Effect of the seawater temperature on the reference function.

Increase in reference function by $2{ }^{\circ} \mathrm{C}$ increases the reference function up to $35 \%$ at lower seawater temperatures. Effect of the Reynolds number on the reference function for the constant pipe diameter is given in Figure 7. As seen in Figure 7 , optimum Reynolds number in the system is about 4000 .

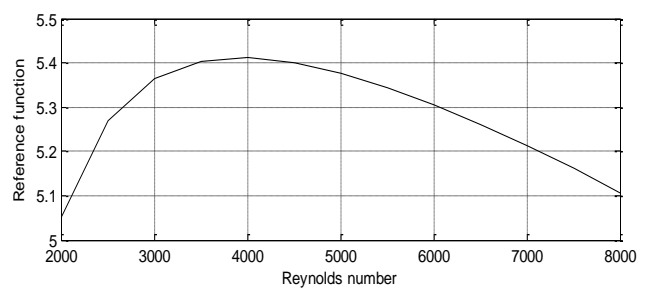

Figure 7: Effect of the Reynolds number on the reference function for the constant pipe diameter.
Increasing the number of the modules also increases the performance as seen in Figure 8. Due to high energy consumption of circulating pump, pipe lengths should not be too long. Pipe lengths can be determined using the reference function where its value is maximum. Also higher module number decreases the reference function because of increasing initial cost.

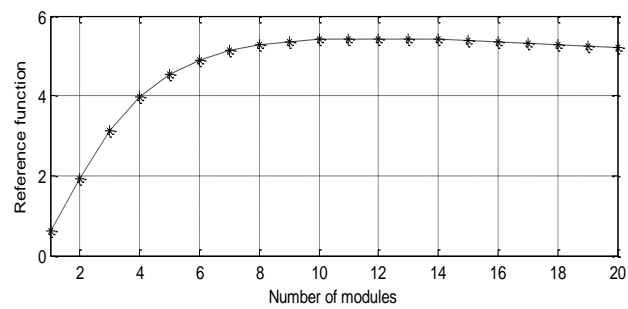

Figure 8: Effect of, number of the modules on the reference function.

\section{Conclusion}

In this study, optimization of the slinky heat exchangers was studied. Effects of bend radius, pipe diameter, pipe wall thickness, seawater temperature, Re number and number of modules were investigated. By composing a reference function, it has been shown the correlation between heat transfer rate and investment and operation costs. Following conclusions achieved from the results of this study:

Bend radius is important if lower than $1 \mathrm{~m}$ especially for smaller diameter pipes,

- Increasing bend radius increases the reference function as required pumping power is reduced,

- Increasing seawater increases the reference function,

- Optimum Reynolds Number is around $R e=4000$ for a given pipe diameter,

- Increasing the number of modules increases the reference function up to 10 modules and there is slight decrease in the reference function. Therefore, the optimum value of number of module is 10 (Figure 8).

\section{Nomenclature}

$a_{\text {pipe }}:$ Annual depreciation for unit length of pipe (TL/ $m$ year),

$b \quad: \quad$ Bend pitch (m),

$b_{1} \quad:$ Annual depreciation for cost of unit circulation pump power (TL/year $\mathrm{kW}$ ),

$b_{2} \quad: \quad$ Annual depreciation for cost of unit heat pump heating capacity (TL/year kW),

$b_{3}, b_{4}$ : Cost of annual operating hours for unit of energy (TL/year kW),

$C_{e} \quad: \quad$ Annual operational cost (TL/year),

$C_{i} \quad:$ Annual depreciation of investment cost (TL/year),

$d_{i} \quad$ : Radius of the circular pipe (m),

$D \quad$ : Pipe diameter $(\mathrm{m})$,

$D_{e} \quad: \quad$ Dean Number (-),

$D_{i} \quad:$ Inner diameter of the pipe $(\mathrm{m})$,

$f_{s}:$ : Friction factor of straight pipe (-)

$f_{c}:$ Friction factor of helical pipe $(-)$,

$g$ : Gravitational acceleration $\left(\mathrm{m} / \mathrm{s}^{2}\right)$,

Gr : Grashof number $(-)$, 


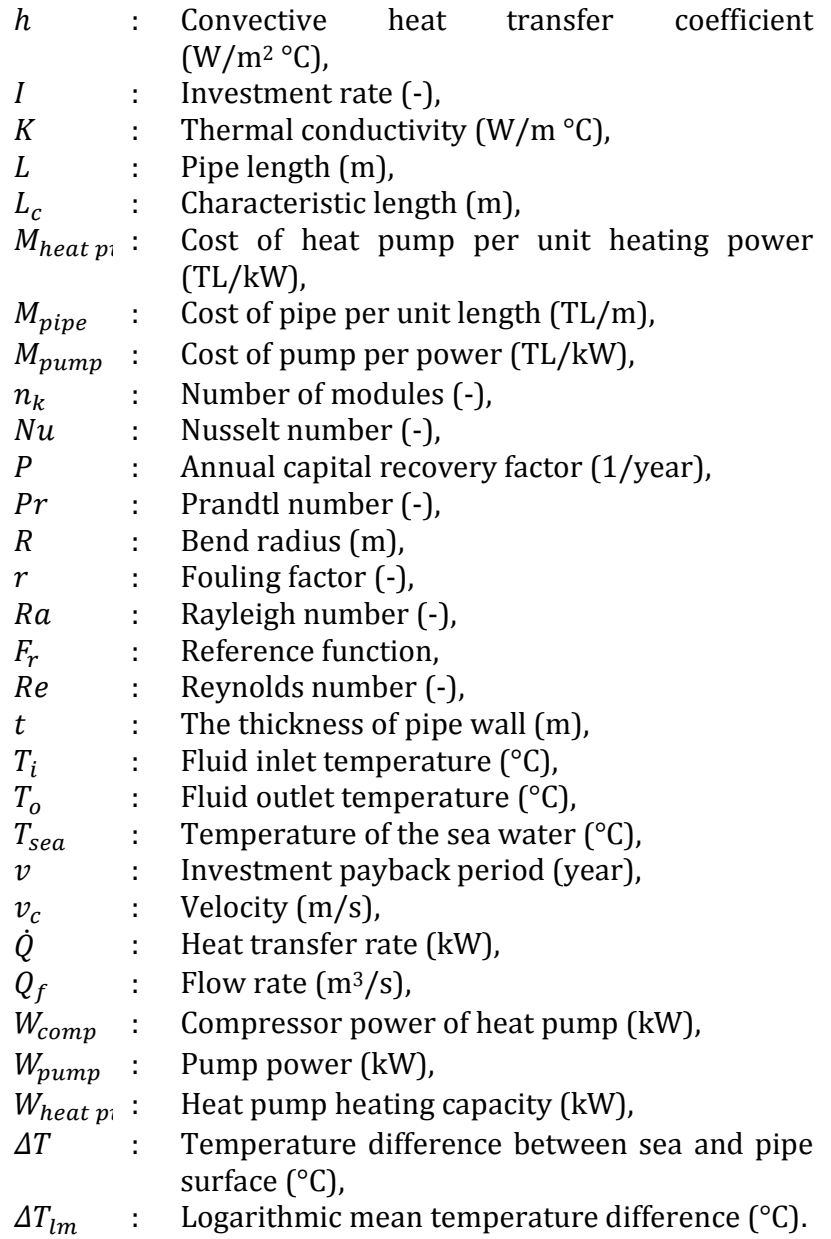

\section{Greek symbols}

\section{References}

[1] Sudiro M, Bertucco A. "Production of synthetic gasoline and diesel fuel by alternative processes using natural gas and coal: Process simulation and optimization" Energy, 34(12), 2206-2214, 2009.

[2] Kılıç A, Yiğit A. Isı Transferi. İstanbul, Turkey, Alfa Publications, 2004.

[3] Streeter V, Wylie E, Bedford K. Fluid Mechanics. New York, USA, McGraw-Hill, 1986.

[4] Yu J, Zhang H, You S. "Heat transfer analysis and experimental verification of casted heat exchanger in non-icing and icing conditions in winter". Renewable Energy, 41, 39-43, 2012.

[5] Haiwen S, Lin D, Xiangli L, Yingxin Z. "Quasi-dynamic energy-saving judgment of electric-driven seawater source heat pump district heating system over boiler house district heating system". Energy and Buildings, 42(12), 2424-2430, 2010.

[6] Demir H. Toprak Kaynaklı Isı Pompası ve Toprak Isı Değiștiricilerinin Optimizasyonu ve Geliştirilmesi. Doktora Tezi, Yıldız Technical University, İstanbul, Turkey, 2006.

[7] Fujii H, Nishi K, Komaniva Y, Chou N. "Numerical modeling of slinky-coil horizontal ground heat exchangers". Geothermics, 41, 55-62, 2012.

[8] Li H, Nagano K, Lai Y. "A new model and solutions for a spiral heat exchanger and its experimental validation". International Journal of Heat and Mass Transfer, 55(15-16), 4404-4414, 2012.

[9] Incropera F, Dewitt D, Bergman TL, Lavine AS., Fundamentals of Heat and Mass Transfer. USA, John Wiley \& Sons, 2007.

[10] Reay DA, Macmichael DBA. Heat Pumps Design and Application. London, England, Pergamon Press, 1979.

[11] Warren RM, James PH, Cho CI. Handbook of Mechanical Engineering. New York, USA, McGraw-Hill, 1998.

[12] Chiasson AD. Advances in Modeling of Ground Source Heat Pump Systems, MSc Thesis, Oklahoma State University, USA, 1999. 